\title{
Article \\ Characterization and Antimicrobial Activity of a Halophyte from the Asturian Coast (Spain): Limonium binervosum (G.E.Sm.) C.E.Salmon
}

\author{
Eva Sánchez-Hernández ${ }^{1} \mathbb{D}$, Laura Buzón-Durán ${ }^{1} \mathbb{D}$, Natalia Langa-Lomba ${ }^{2} \mathbb{D}$, José Casanova-Gascón ${ }^{2} \mathbb{D}$, \\ Belén Lorenzo-Vidal ${ }^{3}$, Jesús Martín-Gil ${ }^{1}$ (D) and Pablo Martín-Ramos ${ }^{2, *(D)}$
}

1 Agriculture and Forestry Engineering Department, ETSIIAA, Universidad de Valladolid, Avenida de Madrid 44, 34004 Palencia, Spain; eva.sanchez.hernandez@uva.es (E.S.-H.); laura.buzon@uva.es (L.B.-D.); mgil@iaf.uva.es (J.M.-G.)

2 Instituto Universitario de Investigación en Ciencias Ambientales de Aragón (IUCA), EPS, Universidad de Zaragoza, Carretera de Cuarte, s/n, 22071 Huesca, Spain; natalialangalomba@gmail.com (N.L.-L.); jcasan@unizar.es (J.C.-G.)

3 Servicio de Microbiología, Hospital Universitario Rio Hortega, Calle Dulzaina 2, 47012 Valladolid, Spain; blorenzov@saludcastillayleon.es

* Correspondence: pmr@unizar.es

Citation: Sánchez-Hernández, E.; Buzón-Durán, L.; Langa-Lomba, N.; Casanova-Gascón, J.; Lorenzo-Vidal, B.; Martín-Gil, J.; Martín-Ramos, P. Characterization and Antimicrobial Activity of a Halophyte from the Asturian Coast (Spain): Limonium binervosum (G.E.Sm.) C.E.Salmon. Plants 2021, 10, 1852. https:// doi.org/10.3390/plants10091852

Academic Editors: Adam Stebel and Maria Iorizzi

Received: 7 August 2021

Accepted: 4 September 2021

Published: 7 September 2021

Publisher's Note: MDPI stays neutral with regard to jurisdictional claims in published maps and institutional affiliations.

Copyright: (c) 2021 by the authors. Licensee MDPI, Basel, Switzerland. This article is an open access article distributed under the terms and conditions of the Creative Commons Attribution (CC BY) license (https:/ / creativecommons.org/licenses/by/ $4.0 /)$.

\begin{abstract}
The work presented herein deals with the characterization and valorization of a halophyte from the cliffs of the Asturian coast: Limonium binervosum (G.E.Sm.) C.E.Salmon (rock sea-lavender). Its biomass and hydromethanolic extracts were studied by elemental and thermal analysis, infrared spectroscopy and gas chromatography-mass spectroscopy. Tetradecanoic acid/esters and 1,2-tetradecanediol were identified in its flower extract, while the leaf extract was rich in linolenic and linoleic acids and their esters, hexadecanoic acid and its esters, and phytol. Both flower and leaf hydromethanolic extracts contained eicosane, sitosterol and tocopherols in significant amounts. With a view to its valorization, the antimicrobial activity of these extracts was investigated against three apple tree and grapevine phytopathogens. Both the hydroalcoholic extracts and their main constituents, alone or in combination with chitosan oligomers (COS), were tested in vitro. A remarkable antibacterial activity was observed for the conjugated complexes of the flower extract with COS, both against Xylophilus ampelinus ( $\mathrm{MIC}=250 \mu \mathrm{g} \cdot \mathrm{mL}^{-1}$ ) and Erwinia amylovora $\left(\mathrm{MIC}=500 \mu \mathrm{g} \cdot \mathrm{mL}^{-1}\right)$, and complete inhibition of the mycelial growth of Diplodia seriata was found at concentrations $<1000 \mu \mathrm{g} \cdot \mathrm{mL}^{-1}$. In view of these results, this extremophile plant can be put forward as a promising source of bioactive metabolites.
\end{abstract}

Keywords: antibacterial; antifungal; Diplodia seriata; Erwinia amylovora; rock sea lavender; Xylophilus ampelinus

\section{Introduction}

Limonium is one of the most important species-rich genera in the Plumbaginaceae family. This widespread genus of halophytes and taxa includes sexual diploids of the L. ovalifolium (Poir.) Kuntze complex, the triploid L. algarvense Erben and the agamospermous tetraploids of the L. binervosum (G.E.Sm.) C.E.Salmon complex [1]. The L. binervosum aggregate is a species group that has not been assigned to any of the subsections of L. sect. Limonium [2] and was first reported in 1922 by Salmon [3].

The habitat of L. binervosum includes coastal cliffs, pebble beach margins, steppes, meadows and lagoons. It grows on the Atlantic coasts of Europe, from the south-west United Kingdom and north-west France to northern Spain, with a number of geographically restricted segregate taxa (Figure 1a). 

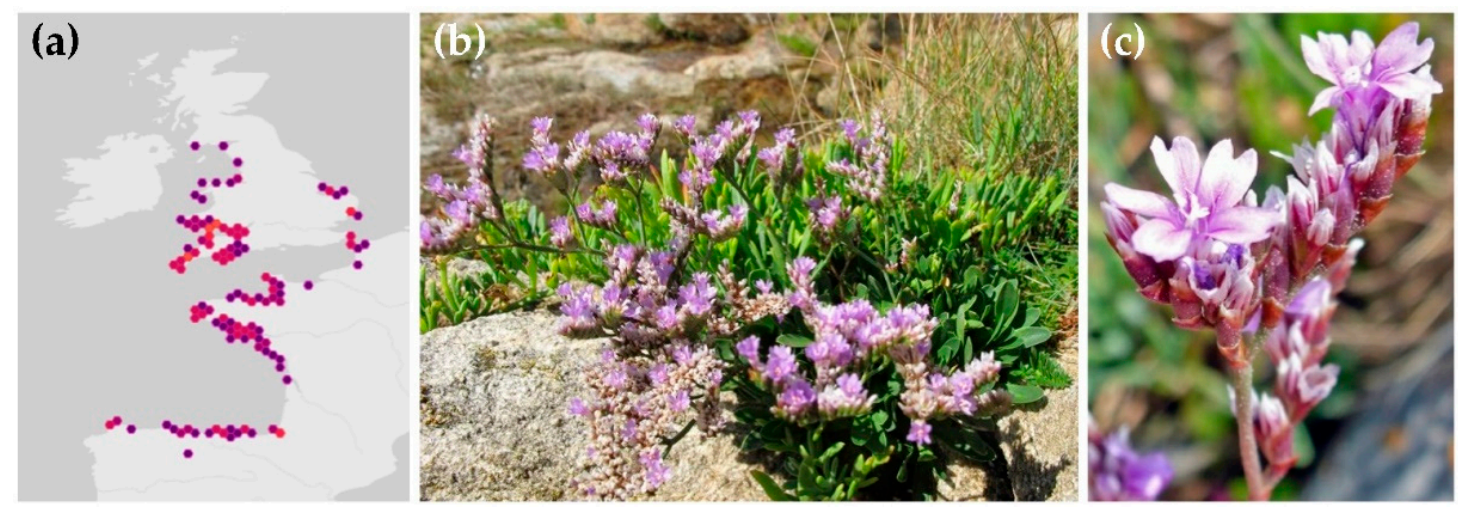

Figure 1. (a) habitat of Limonium binervosum (G.E.Sm.) C.E.Salmon; L. binervosum in cliffs in Llanes (Asturias, Spain): (b) whole plant and (c) flowers. Credit: habitat map generated with OpenStreetMap using GBIF data, under CC BYNC license.

Plants of L. binervosum can grow up to $20 \mathrm{~cm}$, and have regular, straight spikes, which are not aggregated into a corymbose head (Figure 1b). Stems divide several times. Leaves are narrow oblanceolate, greyish-green in color, with a midvein. The flowers form in compact clusters along the leafless stem branches and are pink, formed of five notched petals, with five short stamens topped by white anthers and a purplish calyx (Figure 1c) [4].

A review of the bioactive components in several species of the Limonium genus suggests that they are a good source of antioxidants. For instance, in L. algarvense flowers, the antioxidants are related to gallic acid, catechin, salicylic and rosmarinic acids, and epigallocatechin gallate [5], similar to those found in L. brasiliense (Boiss.) Kuntze (viz. gallic acid, gallocatechin, epigallocatechin, PDE gallate, etc.) [6]. In L. aureum (L.) Hill, the antioxidants identified were myricetin (or cannabiscetine), myricetin-3-O-glucoside, myricetin-3-O- $\beta$-Dglucopyranoside, myricitrin, erioictyol, homoeridictyol, and eriodictyol-7-O-glucoside [7]. In a study on the leaves of L. delicatulum (Girard) Kuntze and L. quesadense Erben it was found that the former is rich in myricetin glycosides, whereas in the latter epigallocatechin gallate and its dimer are some of the most abundant compounds [8]. Consequently, L. binervosum - whose phytochemical constituents have not been studied to date-may also be a promising source of antioxidants.

Taking into consideration that antioxidant activity is generally associated with antibacterial, antifungal and antimycotoxigenic biological activities [9], potential valorization strategies for L. binervosum as a source of bioactive products may be envisaged, aligned with the premises of current EU regulation (Directive 2009/128/EC on the sustainable use of pesticides, Council Regulation (EC) 834/2007 on organic production and labeling of organic products, Regulation (EU) 2019/1009 on the market of EU fertilizing products, etc.), in which the replacement of conventional phytosanitary products with formulations based on natural products is encouraged.

In particular, in this study, its application to the control of grapevine (Vitis vinifera L.) and apple tree (Malus domestica Borkh.) pathogens was explored by assessing its antibacterial activity against Xylophilus ampelinus (Panagopoulos 1969) Willems et al. 1987 and Erwinia amylovora (Burrill), and its antifungal activity against Diplodia seriata De Not.

X. ampelinus (syn. Xanthomonas ampelina and Erwinia vitivora [10]), a quarantine A2 organism according to the European and Mediterranean Plant Protection Organization (EPPO), causes the bacterial necrosis of grapevines ("mal nero" or "maladie d'Oléron"), resulting in yield losses of up to 70\% [11]. E. amylovora, also cataloged as a quarantine organism, causes fire blight, which poses a serious threat to pear and apple production [12] In turn, D. seriata, a Botryosphaeriaceous fungus, causes dieback, canker, leaf spot and fruit rot in a wide range of hosts, including grapevine $[13,14]$ and apple trees [15-17].

With a view to a possible valorization of this halophyte (L. binervosum), a physicochemical characterization is presented, together with an in vitro evaluation of the antimicrobial 
activity of its extracts-alone and in combination with chitosan oligomers-against aforementioned phytopathogens.

\section{Results}

\subsection{Elemental Analysis and Calorific Values Calculation}

The $\mathrm{C}, \mathrm{H}, \mathrm{N}$ and $\mathrm{S}$ percentages of L. binervosum components (wt $\%$ of dry material) were in the $40.5-44.7 \%, 6.4-6.5 \%, 1.2-2.6 \%$ and $0.2-0.9 \%$ range, respectively (Table 1 )

Table 1. Elemental composition (wt $\%$ ) of L. binervosum fractions.

\begin{tabular}{ccccccc}
\hline Fraction & $\mathbf{C}$ & $\mathbf{H}$ & $\mathbf{N}$ & $\mathbf{S}$ & $\mathbf{O}$ & C/N Ratio \\
\hline Flowers & $44.7 \%$ & $6.5 \%$ & $1.3 \%$ & $0.3 \%$ & $47.2 \%$ & 34.9 \\
Leaves & $40.5 \%$ & $6.4 \%$ & $2.6 \%$ & $0.9 \%$ & $49.6 \%$ & 15.7 \\
\hline
\end{tabular}

Higher heating values derived from elemental analysis data resulted in heating values for flowers and leaves of 18 and $16 \mathrm{~kJ} \cdot \mathrm{g}^{-1}$, respectively.

\subsection{Thermal Analyses}

The TG, DTG and DSC curves of flowers and leaves are shown in Figures S1 and S2, respectively. In the case of flowers, exothermal effects were detected at 329, 420 and $470{ }^{\circ} \mathrm{C}$; the ash content (at $550{ }^{\circ} \mathrm{C}$ ) was $5.6 \%$. Concerning leaves, exothermal effects were registered at 320 and $470{ }^{\circ} \mathrm{C}$, and the ash content (at $580{ }^{\circ} \mathrm{C}$ ) reached $17 \%$. For comparison purposes, the total ash content reported L. stocksii (Boiss.) Kuntze was 11.83\% [18].

\subsection{Vibrational Characterization}

The main absorption bands in the FTIR spectra of the powdered dry samples of flowers and leaves are summarized in Table 2, together with their assignments. The bands at $2918,2850,1462$ and $720 \mathrm{~cm}^{-1}$ are due to aliphatic features and are present in straightchain alkanes (compatible with the presence of tetracosane, pentacosane, heptacosane, etc., identified by GC-MS in the extracts, as discussed below) [19]. The band at $2158 \mathrm{~cm}^{-1}$, ascribed to $\mathrm{C}-\mathrm{N}$ stretching, may arise from the presence of carbonitrogenated compounds (e.g., n-methyl-1-adamantaneacetamide; 2-(4-fluoro-phenyl)-4-(3-methyl-benzylidene)-4hoxazol-5-one, 2-ethylacridine, etc.) [20]. The bands at ca. 1730 and ca. $1165 \mathrm{~cm}^{-1}$, related to carbonyl $(\mathrm{C}=\mathrm{O})$ stretching and $\mathrm{C}-\mathrm{C}(=\mathrm{O})-\mathrm{O}$ stretching, respectively, illustrate the main spectral features of esters (e.g., 2-hydroxy-tetradecanoic acid methyl ester; hexadecanoic acid methyl ester; 9,12-octadecadienoic acid methyl ester; 9,12,15-octadecatrienoic acid methyl ester, etc.) [19]. The band at ca. $1640 \mathrm{~cm}^{-1}$, resulting from $\mathrm{C}=\mathrm{O}$ and $\mathrm{C}=\mathrm{C}$ stretching vibrations and asymmetric $\mathrm{N}-\mathrm{H}$ bending vibrations, can be due to flavonoids and lipids [21,22]. The bands at 1513 and $1417 \mathrm{~cm}^{-1}$, related to aromatic $\mathrm{C}=\mathrm{C}$ stretching, are compatible with the presence of flavonoids and aromatic rings. The band at $1235 \mathrm{~cm}^{-1}$ may be due to $\mathrm{C}-\mathrm{O}$ group vibration in polyols, such as hydroxyflavonoids [23].

The FTIR spectrum of the lyophilized flower hydromethanolic extract (not included in Table 2) showed bands at 3362, 2917, 2849, 1733sh, 1636, 1462, 1340, 1228, 1067 and $957 \mathrm{~cm}^{-1}$, attributable to tetradecanoic $\left(1727,1448,1310 \mathrm{~cm}^{-1}\right)$ and eicosane $(2914,2847$ and $\left.1471 \mathrm{~cm}^{-1}\right)$.

\subsection{Hydromethanolic Extracts Characterization}

\subsubsection{Phenolic Contents}

The total phenolic content of the flower and leaf extracts were $162 \pm 7$ and $58 \pm 2 \mathrm{mg}$ GAE/g DW, respectively. 
Table 2. Main bands in the FTIR spectra of L. binervosum flowers and leaves and their assignments. Peak positions are expressed in $\mathrm{cm}^{-1}$.

\begin{tabular}{|c|c|c|}
\hline \multicolumn{2}{|c|}{ Fraction } & \multirow{2}{*}{ Assignment } \\
\hline Flowers & Leaves & \\
\hline & 3382 & Bonded O-H stretching (cellulose) \\
\hline 2921 & 2918 & $-\mathrm{CH}_{2}$ asymmetric stretching of alkyls \\
\hline 2852 & 2850 & $-\mathrm{CH}_{2}$ symmetric stretching; $\mathrm{CH}_{2}-(\mathrm{C} 6)-$ bending (cellulose) \\
\hline 2158 & & CN stretching \\
\hline 1731 & 1728 & $\mathrm{C}=\mathrm{O}$ stretching of alkyl ester \\
\hline 1653 & 1636 & Amide $\mathrm{I} ; \mathrm{C}=\mathrm{C}$ stretching; $\mathrm{C}=\mathrm{O}$ stretching \\
\hline 1605 & 1617 & Aromatic $\mathrm{C}=\mathrm{C}$ skeletal stretching; $\mathrm{COO}^{-}$antisymmetric stretching (polygalacturonic, pectin ester) \\
\hline 1558 & & Amide II; $\mathrm{COO}^{-}$symmetric stretching; polynuclear aromatics \\
\hline 1515 & 1517 & $\mathrm{C}=\mathrm{C}$ stretching vibrations of aromatic structures \\
\hline $\begin{array}{l}1457 \\
1441\end{array}$ & 1462 & $\mathrm{O}-\mathrm{CH}_{3}$ stretching; $\mathrm{C}-\mathrm{H}$ bending of $\mathrm{CH}_{2}$ or $\mathrm{CH}_{3}$ \\
\hline & 1417 & $\mathrm{CH}_{2}$ symmetric bending; aromatic $\mathrm{C}=\mathrm{C}$; $\mathrm{COO}$ symmetric stretching \\
\hline 1362 & 1372 & C-H (cellulose) \\
\hline 1236 & 1236 & $\begin{array}{l}\text { Amide III; } \mathrm{C}-\mathrm{C}-\mathrm{O} \text { asymmetric stretching acetylated glucomannan; } \mathrm{C}-\mathrm{O} \text { stretching of aryl ether; } \mathrm{C}-\mathrm{O} \text { and } \\
\qquad \mathrm{OH} \text { of } \mathrm{COOH} \text { groups }\end{array}$ \\
\hline 1162 & 1168 & $\mathrm{C}-\mathrm{O}-\mathrm{C}$ in bridge asymmetric; $\mathrm{C}-\mathrm{C}$ in plane \\
\hline 1100 & 1104 & $\mathrm{C}-\mathrm{O}-\mathrm{C}$ symmetric stretching \\
\hline 1017 & 1021 & C-H bending (typical of carotenes); polygalacturonic acid (a variety of pectin in plant cuticles) \\
\hline & 874 & $\beta$-glycosidic linkages (glucose units of cellulose chains) \\
\hline 832 & 830 & $\mathrm{O}-\mathrm{C}=\mathrm{O}$ in-plane deformation or a $\mathrm{CH}_{2}$ rocking deformation \\
\hline 720 & & In-plane bending or rocking of the methylenes $\left(-\mathrm{CH}_{2}-\right)$ \\
\hline 668 & & C-C out-of-plane bending \\
\hline
\end{tabular}

\subsubsection{Analysis of Hydromethanolic Extracts by GC-MS}

The main constituents identified in the flower hydromethanolic extract (Tables 3 and S1, and Figure S3) were: tetradecanoic acid and methyl 2-hydroxy tetradecanoate (22\%); eicosane (18\%); 1,2-tetradecanediol (15\%); sitosterol (9\%); tocopherols/vitamin E (7\%); and $n$-alcanes (heneicosane, tetracosane, pentacosane, heptacosane, etc., which add up to $6 \%$ ). Among the minority constituents, it is necessary to highlight the presence of 2-ethyl-acridine (1.6\%) as the only carbonitrogenated compound.

Concerning the main phytoconstituents identified in the leaf extract (Tables 4 and S2, and Figure S4), they were: octadecatrienoic acid (linolenic acid) and their esters (above $22 \%)$; sitosterol (19\%); hexadecanoic acid and their esters (above 15\%); octadecadienoic acid or linoleic acid (8\%); vitamin E (8\%) and other tocopherols (5\%); trans-pinane (5\%); eicosane (4\%); and phytol (4\%).

\subsection{Antimicrobial Activity}

\subsubsection{In Vitro Antibacterial Activity}

The inhibition of flower and leaf extracts against X. ampelinus and E. amylovora were similar and comparable to that attained with COS (Table 5). Regarding the activities of the main active principles present in the extracts, differences were observed as a function of the pathogen: while tetradecanoic acid, linolenic acid and vitamin E showed similar activity against $X$. ampelinus ( $\mathrm{MIC}=500 \mu \mathrm{g} \cdot \mathrm{mL}^{-1}$ ), tetradecanoic acid was the most effective against E. amylovora $\left(\mathrm{MIC}=500 \mu \mathrm{g} \cdot \mathrm{mL}^{-1}\right)$, and linolenic acid and vitamin E were less effective $\left(\mathrm{MIC}=750 \mu \mathrm{g} \cdot \mathrm{mL}^{-1}\right) . \quad \beta$-sitosterol showed worse performance than the former three (MIC $=1000$ and $1500 \mu \mathrm{g} \cdot \mathrm{mL}^{-1}$ against X. ampelinus and E. amylovora, respectively), and eicosane was the least effective (MIC $=1000$ and $>1500 \mu \mathrm{g} \cdot \mathrm{mL}^{-1}$ against $X$. ampelinus and E. amylovora, respectively). 
Table 3. Main compounds identified in L. binervosum flower hydromethanolic extract by GC-MS.

\begin{tabular}{|c|c|c|c|c|c|}
\hline Peak & $\mathbf{R}_{\mathbf{t}}(\min )$ & Area $(\%)$ & Assignment & MW (Da) & Qual \\
\hline 2 & 11.842 & 0.92 & $\begin{array}{c}\text { geranyl acetate or 2,6-octadien-1-ol, 3,7-dimethyl-, } \\
\text { acetate (stereoisomers) }\end{array}$ & 196.3 & $90 ; 86$ \\
\hline 3 & 17.154 & 1.03 & $\begin{array}{c}\text { bicyclo[3.1.1] heptane, 2,6,6-trimethyl-, }(1 \alpha, 2 \beta, 5 \alpha) \text { (also } \\
\text { named trans-pinane) }\end{array}$ & 138.3 & 90 \\
\hline 6 & 18.405 & 4.94 & tetradecanoic acid & 228.4 & 93 \\
\hline 7 & 19.666 & 1.07 & heneicosane; hexacosane & $296.6 ; 366.7$ & $98 ; 92$ \\
\hline 11 & 21.458 & 17.61 & eicosane; hexadecane, 2,6,10,14-tetramethyl-; heptadecane & $\begin{array}{l}282.5 ; 282.5 \\
\quad 240.5\end{array}$ & $97 ; 97 ; 96$ \\
\hline 13 & 23.060 & 3.36 & heneicosane; pentacosane & $296.6 ; 352.7$ & $96 ; 93$ \\
\hline 17 & 24.608 & 16.87 & $\begin{array}{c}\text { tetradecanoic acid, 2-hydroxy-, methyl ester (or methyl } \\
\text { 2-hydroxy tetradecanoate) }\end{array}$ & 258.4 & 93 \\
\hline 18 & 25.095 & 1.66 & tetracosane; heptadecane, 9-octyl-; tricosane, 2-methyl- & $\begin{array}{l}338.7 ; 352.7 \\
\quad 338.7\end{array}$ & $93 ; 93 ; 86$ \\
\hline 19 & 25.309 & 1.26 & 1,2-tetradecanediol & 230.4 & 64 \\
\hline 20 & 25.538 & 2.35 & squalene & 410.7 & 98 \\
\hline 21 & 25.592 & 1.21 & pentacosane, 13-undecyl-; heneicosane, 3-methyl- & $507 ; 310.6$ & $52 ; 38$ \\
\hline 22 & 25.708 & 0.90 & octacosane; hexacosane & $394.8 ; 366.7$ & $99 ; 98$ \\
\hline 23 & 26.025 & 14.37 & 1,2-tetradecanediol & 230.4 & 90 \\
\hline 28 & 27.252 & 1.13 & $\gamma$-tocopherol & 416.7 & 98 \\
\hline 29 & 27.554 & 1.23 & fumaric acid, 3,5-difluorophenyl dodecyl ester; Z-14-nonacosane & $396.5 ; 406.8$ & $68 ; 64$ \\
\hline 30 & 27.607 & 3.19 & octacosyl trifluoroacetate; tetratriacontyl pentafluoropropionate & $506.8 ; 640.9$ & $38 ; 38$ \\
\hline 31 & 27.992 & 5.56 & vitamin $\mathrm{E} ; \mathrm{dl}$ - $\alpha$-tocopherol & $430.7 ; 430.7$ & $99 ; 99$ \\
\hline 33 & 29.112 & 1.74 & campesterol & 400.7 & 62 \\
\hline 34 & 30.173 & 8.83 & $\gamma$-sitosterol; $\beta$-sitosterol & $414.7 ; 414.7$ & $99 ; 95$ \\
\hline 35 & 31.166 & 1.59 & 2-ethylacridine & 207.3 & 90 \\
\hline
\end{tabular}

Rt: retention time; MW: molecular weight; Qual: percentage of similarity between the molecules present in the sample and those registered in the NIST11 library. When more than one possible assignment is indicated, MW and Qual values for each of the compounds are separated by a semicolon.

Upon conjugation with COS, a synergistic behavior was observed for all phytochemicals. The best results against $X$. ampelinus were attained with the COS-flower extract conjugate complex $\left(\mathrm{MIC}=250 \mu \mathrm{g} \cdot \mathrm{mL}^{-1}\right)$, comparable to those attained for the COStetradecanoic acid, COS-linolenic acid and COS-vitamin E conjugate complexes, while the effectiveness of the COS-leaf extract was lower $\left(\mathrm{MIC}=500 \mu \mathrm{g} \cdot \mathrm{mL}^{-1}\right)$. In the case of E. amylovora, the COS-flower extract conjugate complex was more effective than the leaf-based one (MIC $=500 \mu \mathrm{g} \cdot \mathrm{mL}^{-1} \mathrm{vs} .750 \mu \mathrm{g} \cdot \mathrm{mL}^{-1}$, respectively), but less effective than the COS-tetradecanoic acid, COS-linolenic acid and COS-vitamin E conjugate complexes (MIC $=250 \mu \mathrm{g} \cdot \mathrm{mL}^{-1}$, similar to those observed against $X$. ampelinus).

\subsubsection{In Vitro Antifungal Activity}

The results from the D. seriata mycelial growth inhibition tests are shown in Figures 2 and S5. At the highest dose $\left(1500 \mu \mathrm{g} \cdot \mathrm{mL}^{-1}\right)$, the flower and the leaf extracts resulted in $82 \%$ and $71 \%$ inhibition, respectively, while full inhibition was attained at $750 \mu \mathrm{g} \cdot \mathrm{mL}^{-1}$ for tetradecanoic acid, linolenic acid and vitamin E constituents, and at $250 \mu \mathrm{g} \cdot \mathrm{mL}^{-1}$ for $\beta$-sitosterol. In the case of eicosane, 93\% inhibition was observed at the highest dose.

The formation of conjugate complexes improved the activity in all cases, with remarkable improvements in COS-tetradecanoic and COS-linolenic (from 750 down to $\left.187.5 \mu \mathrm{g} \cdot \mathrm{mL}^{-1}\right)$. Concerning flower and leaf extracts, full inhibition was attained at $1000 \mu \mathrm{g} \cdot \mathrm{mL}^{-1}$ in both cases.

Determination of $\mathrm{EC}_{50}$ and $\mathrm{EC}_{90}$ values $(50 \%$ and $90 \%$ maximal effective concentration, respectively), summarized in Table 6, and calculation of synergy factors, presented in Table 7, confirmed the strong synergistic behavior previously mentioned for COS and tetradecanoic and linolenic acids (with SFs of 4.55 and 5.75 for the $\mathrm{EC}_{90}$, respectively). In all the other cases, $\mathrm{SFs}>1$ (i.e., indicative of a synergistic behavior) were also obtained, albeit more moderate. 
Table 4. Main compounds identified in L. binervosum leaf hydromethanolic extract by GC-MS.

\begin{tabular}{|c|c|c|c|c|c|}
\hline Peak & $\mathbf{R}_{\mathrm{t}}(\min )$ & Area $(\%)$ & Assignment & MW (Da) & Qual \\
\hline 1 & 17.154 & 5.41 & $\begin{array}{l}\text { bicyclo[3.1.1]heptane, 2,6,6-trimethyl-, }(1 \alpha, 2 \beta, 5 \alpha) \text { (also named } \\
\text { (-)-trans-pinane); 3-octadecyne }\end{array}$ & $138.3 ; 250.5$ & $64 ; 58$ \\
\hline 4 & 17.593 & 2.20 & cyclohexanol, 1-ethynyl-; phytol, acetate; 1-hexadecyne & $\begin{array}{l}\text { 124.2; } 338.6 ; \\
\quad 222.4\end{array}$ & $38 ; 38 ; 38$ \\
\hline 5 & 18.026 & 9.83 & hexadecanoic acid, methyl ester & 270.5 & 99 \\
\hline 6 & 18.386 & 4.25 & $n$-hexadecanoic acid; $n$-decanoic acid & $256.4 ; 172.3$ & $99 ; 90$ \\
\hline 7 & 19.667 & 7.63 & 9,12-octadecadienoic acid (Z,Z)-, methyl ester & 294.5 & 99 \\
\hline 8 & 19.740 & 22.26 & $\begin{array}{l}\text { 9,12,15-octadecatrienoic acid, methyl ester, (Z,Z,Z)-; 9,12,15-octadecatrienoic } \\
\text { acid, (Z,Z,Z)- }\end{array}$ & $292.5 ; 278.4$ & $99 ; 95$ \\
\hline 9 & 19.832 & 3.80 & phytol & 296.5 & 98 \\
\hline 12 & 25.538 & 1.08 & squalene & 410.7 & 99 \\
\hline 13 & 25.962 & 2.82 & nonacosane; eicosane; docosane & $\begin{array}{l}408.8 ; 282.5 \\
\quad 310.6\end{array}$ & $99 ; 98 ; 96$ \\
\hline 14 & 26.415 & 1.77 & $\begin{array}{l}\quad \delta \text {-tocotrienol (or 2H-1-benzopyran-6-ol, } \\
\left.\left.\left.\text { 3,4-dihydro-2,8-dimethyl-2-(4,8,12-trimethyltridecyl)-, [2R-[2* }\left(4 \mathrm{R}^{*}, 8 \mathrm{R}^{*}\right)\right]\right]-\right)\end{array}$ & 396.6 & 98 \\
\hline 15 & 27.125 & 1.14 & $\beta$-tocopherol & 416.7 & 99 \\
\hline 16 & 27.252 & 1.84 & $\gamma$-tocopherol; $\beta$-tocopherol; $\delta$-tocopherol, o-methyl- & $\begin{array}{l}416.7 ; 416.7 ; \\
\quad 416.7\end{array}$ & $97 ; 94 ; 94$ \\
\hline 17 & 27.476 & 1.21 & $\begin{array}{c}\text { eicosane; octadecane } \\
1 \text { H-indole-2-carboxylic acid, }\end{array}$ & $282.5 ; 254.5$ & $96 ; 96$ \\
\hline 18 & 27.607 & 1.57 & $\begin{array}{l}\text { 6-(4-ethoxyphenyl)-3-methyl-4-oxo-4,5,6,7-tetrahydro-, isopropyl ester; } \\
n \text {-methyl-1-adamantaneacetamide }\end{array}$ & $355.4 ; 207.31$ & $40 ; 38$ \\
\hline 19 & 27.987 & 8.08 & $\alpha$-tocopherol & 416.7 & 99 \\
\hline 20 & 28.070 & 1.35 & $\begin{array}{c}\text { phytol, acetate; } \\
\text { 2-(4-fluoro-phenyl)-4-(3-methyl-benzylidene)-4h-oxazol-5-one }\end{array}$ & $338.6 ; 281.3$ & $49 ; 43$ \\
\hline 21 & 30.163 & 19.15 & $\gamma$-sitosterol; $\beta$-sitosterol & $414.7 ; 414.7$ & $99 ; 99$ \\
\hline
\end{tabular}

Rt: retention time; MW: molecular weight; Qual: percentage of similarity between the molecules present in the sample and those registered in the NIST11 library. When more than one possible assignment is indicated, MW and Qual values for each of the compounds are separated by a semicolon.

Table 5. Antibacterial activity of chitosan oligomers (COS), L. binervosum flower and leaf hydromethanolic extracts, their main constituents (eicosane, tetradecanoic acid, linolenic acid, $\beta$-sitosterol and vitamin $\mathrm{E}$ ), and their corresponding conjugate complexes (COS-flower extract, COS-leaf extract, COS-eicosane, COS-tetradecanoic acid, COS-linolenic acid, COS- $\beta$ sitosterol and COS-vitamin E) against the two phytopathogenic bacteria under study at different concentrations (expressed in $\left.\mu \mathrm{g} \cdot \mathrm{mL}^{-1}\right)$.

\begin{tabular}{|c|c|c|c|c|c|c|c|c|c|c|c|}
\hline \multirow{2}{*}{ Pathogen } & \multirow{2}{*}{ Compound } & \multicolumn{10}{|c|}{ Concentration $\left(\mu \mathrm{g} \cdot \mathrm{mL}^{-1}\right)$} \\
\hline & & 62.5 & 93.75 & 125 & 187.5 & 250 & 375 & 500 & 750 & 1000 & 1500 \\
\hline \multirow{15}{*}{ X. ampelinus } & $\cos$ & + & + & + & + & + & + & + & + & + & - \\
\hline & Flower extract & + & + & + & + & + & + & + & + & + & - \\
\hline & Leaf extract & + & + & + & + & + & + & + & + & + & - \\
\hline & Eicosane & + & + & + & + & + & + & + & + & - & - \\
\hline & $\beta$-sitosterol & + & + & + & + & + & + & + & + & - & - \\
\hline & Tetradecanoic acid & + & + & + & + & + & + & - & - & - & - \\
\hline & Linolenic acid & + & + & + & + & + & + & - & - & - & - \\
\hline & Vitamin E & + & + & + & + & + & + & - & - & - & - \\
\hline & COS-flower extract & + & + & + & + & - & - & - & - & - & - \\
\hline & COS-leaf extract & + & + & + & + & + & + & + & - & - & - \\
\hline & COS-eicosane & + & + & + & + & + & + & + & - & - & - \\
\hline & COS- $\beta$-sitosterol & + & + & + & + & + & + & - & - & - & - \\
\hline & COS-tetradecanoic acid & + & + & + & + & - & - & - & - & - & - \\
\hline & COS-linolenic acid & + & + & + & + & - & - & - & - & - & - \\
\hline & COS-vitamin E & + & + & + & + & - & - & - & - & - & - \\
\hline \multirow{15}{*}{ E. amylovora } & $\cos$ & + & + & + & + & + & + & + & + & + & - \\
\hline & Flower extract & + & + & + & + & + & + & + & + & + & - \\
\hline & Leaf extract & + & + & + & + & + & + & + & + & + & - \\
\hline & Eicosane & + & + & + & + & + & + & + & + & + & + \\
\hline & $\beta$-sitosterol & + & + & + & + & + & + & + & + & + & - \\
\hline & Tetradecanoic acid & + & + & + & + & + & + & - & - & - & - \\
\hline & Linolenic acid & + & + & + & + & + & + & - & - & - & - \\
\hline & Vitamin E & + & + & + & + & + & + & + & - & - & - \\
\hline & COS-flower extract & + & + & + & + & + & + & - & - & - & - \\
\hline & COS-leaf extract & + & + & + & + & + & + & + & - & - & - \\
\hline & COS-eicosane & + & + & + & + & + & + & + & + & + & - \\
\hline & COS- $\beta$-sitosterol & + & + & + & + & + & - & - & - & - & - \\
\hline & COS-tetradecanoic acid & + & + & + & + & - & - & - & - & - & - \\
\hline & COS-linolenic acid & + & + & + & + & - & - & - & - & - & - \\
\hline & COS-vitamin E & + & + & + & + & - & - & - & - & - & - \\
\hline
\end{tabular}



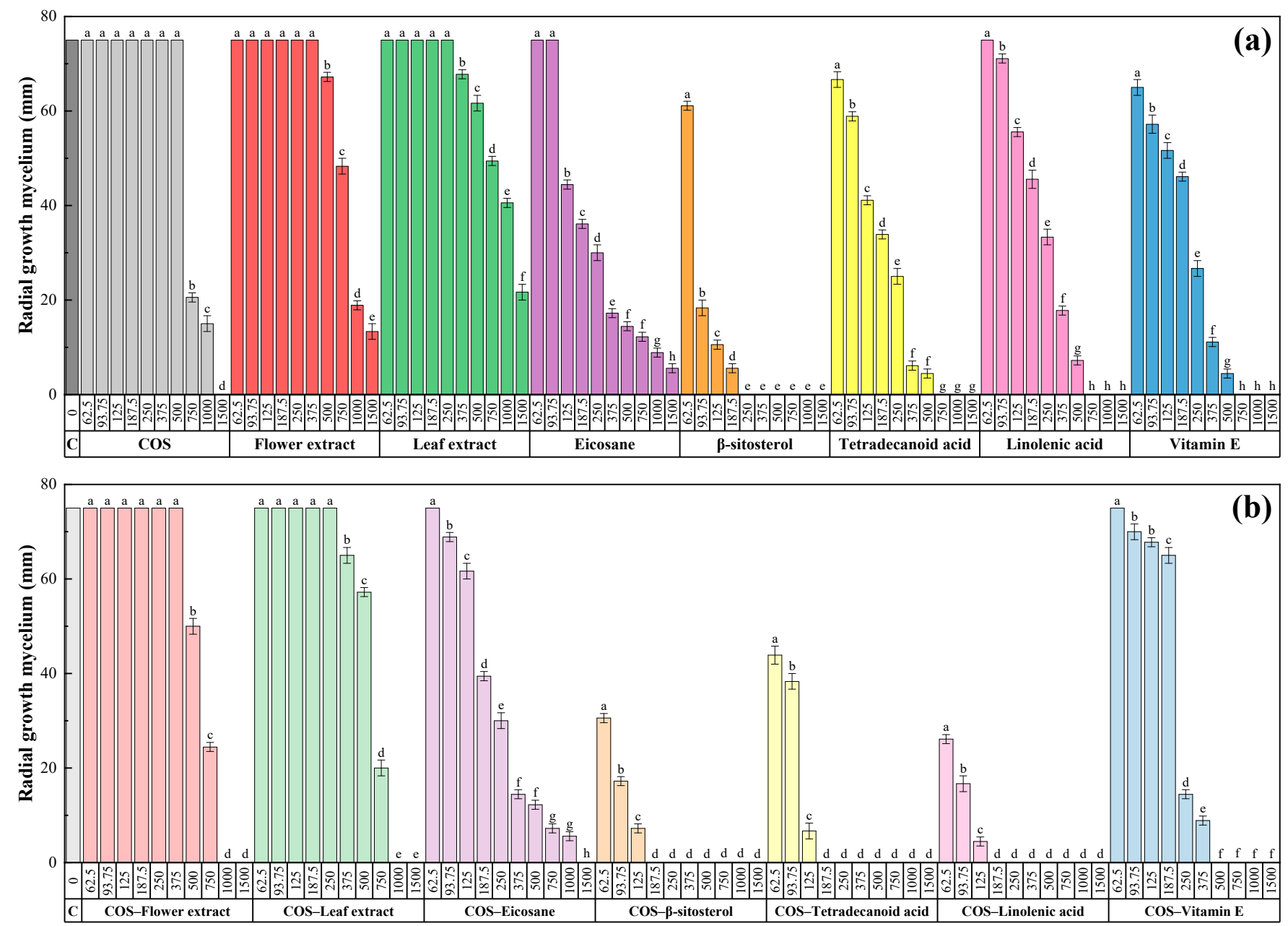

Figure 2. Radial growth of the mycelium for D. seriata in in vitro tests conducted in PDA medium with different concentrations $\left(62.5,93.75,125,187.5,250,375,500,750,1000\right.$ and $\left.1500 \mu \mathrm{g} \cdot \mathrm{mL}^{-1}\right)$ of chitosan oligomers (COS), L. binervosum flower and leaf extracts, and their main phytochemical constituents (a), and their respective conjugate complexes (b). The same letters above concentrations mean that they are not significantly different at $p<0.05$. Error bars represent standard deviations.

Table 6. $\mathrm{EC}_{50}$ and $\mathrm{EC}_{90}$ effective concentrations for the different treatments, expressed in $\mu \mathrm{g} \cdot \mathrm{mL}^{-1}$.

\begin{tabular}{ccccccccc}
\hline EC & COS & Flower Extract & Leaf Extract & Eicosane & $\beta$-Sitosterol & Tetradecanoic & Linolenic & Vitamin E \\
\hline EC $_{50}$ & $744 \pm 42$ & $845 \pm 19$ & $1033 \pm 107$ & $154 \pm 29$ & $82 \pm 11$ & $153 \pm 17$ & $227 \pm 17$ & $212 \pm 13$ \\
$\mathrm{EC}_{90}$ & $1180 \pm 46$ & $1555 \pm 71$ & $2167 \pm 215$ & $1023 \pm 96$ & $151 \pm 26$ & $394 \pm 49$ & $538 \pm 73$ & $434 \pm 57$ \\
\hline \multirow{2}{*}{ EC } & & COS-Flower & COS-Leaf & COS- & COS- $\beta-$ & COS- & COS- & COS- \\
& & Extract & Extract & Eicosane & Sitosterol & Tetradecanoic & Linolenic & Vitamin E \\
\hline EC $_{50}$ & & $611 \pm 33$ & $625 \pm 20$ & $234 \pm 13$ & $51 \pm 2$ & $109 \pm 2$ & $39 \pm 1$ & $217 \pm 7$ \\
EC $_{90}$ & & $914 \pm 75$ & $966 \pm 64$ & $678 \pm 54$ & $124 \pm 4$ & $130 \pm 4$ & $129 \pm 8$ & $406 \pm 10$ \\
\hline
\end{tabular}

Table 7. Synergy factors, estimated according to Wadley's method, for the conjugate complexes under study.

\begin{tabular}{cccccccc}
\hline EC & $\begin{array}{c}\text { COS-Flower } \\
\text { Extract }\end{array}$ & $\begin{array}{c}\text { COS-Leaf } \\
\text { Extract }\end{array}$ & $\begin{array}{c}\text { COS- } \\
\text { Eicosane }\end{array}$ & $\begin{array}{c}\text { COS- } \beta- \\
\text { Sitosterol }\end{array}$ & $\begin{array}{c}\text { COS- } \\
\text { Tetradecanoic }\end{array}$ & $\begin{array}{c}\text { COS- } \\
\text { Linolenic }\end{array}$ & $\begin{array}{c}\text { COS- } \\
\text { Vitamin E }\end{array}$ \\
\hline EC $_{50}$ & 1.30 & 1.38 & 1.09 & 2.90 & 2.33 & 8.98 & 1.52 \\
$\mathrm{EC}_{90}$ & 1.47 & 1.58 & 1.63 & 2.15 & 4.55 & 5.75 & 1.56 \\
\hline
\end{tabular}




\section{Discussion}

\subsection{Elemental Analysis and Calorific Values Calculation}

In relation to the elemental analysis results, the carbon content is close to that reported by Park et al. [24] for L. tetragonum (Thunb.) Bullock (45.5\%), while the nitrogen content in leaves is in good agreement with that reported for L. echioides (L.) Mill. (ca. 2.4\%) for complete shoots [25]. The fact that the values of the $\mathrm{C} / \mathrm{N}$ ratios for flowers are twice those obtained for leaves is consistent with the higher percentage of carbonitrogenated compounds in leaves (viz. n-methyl-1-adamantaneacetamide, and 2-(4-fluoro-phenyl)-4(3-methyl-benzylidene)-4h-oxazol-5-one, which account for ca. 3\% according to GC-MS results) than in flowers (viz. 2-ethylacridine, 1.59\%).

The calorific values obtained from elemental analysis data, below the $18.82 \mathrm{~kJ} \cdot \mathrm{g}^{-1}$ limit required in EN 14961-2 [26], and the high ash contents (above the $2 \%$ limit), preclude the valorization of this halophyte as solid biofuel. Nonetheless, it is worth noting that the fatty acid profile (discussed below), rich in linolenic and linoleic acids, can make L. binervosum a promising biofuel feedstock, according to Patel et al. [27].

\subsection{Phytochemical Composition}

The eicosane content in the flower extract $(18 \%)$ is higher than the one reported in the aerial parts of L. leptophyllum (Schrenk) Kuntze (8\%) [28]. Concerning $\beta$-sitosterol, its presence was reported in the rhizome of L. brasiliense [6], L. myrianthum (Schrenk) Kuntze [28], L. gmelinii (Willd.) Kuntze and L. popovii Kubansk. [29] and in the aerial parts of L. axillare (Forssk.) Kuntze [30]. Tetradecanoic, linolenic and linoleic acids were reported in the aerial parts and roots of L. gmelinii and L. popovii [29], with contents in the $1-4 \%, 11-27 \%$ and $15-32 \%$ range, respectively (vs. $22 \%, 22 \%$ and $8 \%$, respectively, for L. binervosum).

Although flavonol myricetin (3,5,7-trihydroxy-2-(3,4,5-trihydroxyphenyl)-4-chromenone), reported for L. aureum [7] and L. delicatulum [8], was not found among the phytochemicals identified by GC-MS in our experimental conditions, significant amounts (7-13\%) of antioxidants alternative to myricetin, such as the $\alpha-, \beta-, \gamma$ - and $\delta$-tocopherols (e.g., 2-[(4R,8R)-4,8,12-trimethyltridecyl]-3,4-dihydrochromen-6-ol natural vitamin E constituents) were identified. This feature is important because in the literature [31,32] some antimicrobial activity was advocated for myricetin analogs, and a synergistic antioxidant effect of $\alpha$-tocopherol and myricetin was described [33].

Concerning the TPC of the flower extract (162 mg GAE/g DW), it was higher than those reported for L. sinuatum (L.) Mill. flowers (23-34 mg GAE/g DW) [34,35], but lower than those reported for L. algarvense flower methanol extract (228 mg GAE/g DW) [5]. In regards to the TPC in the leaf extract (58 mg GAE/g DW), it was similar to those reported for L. delicatulum shoot extracts (47 mg GAE/g DW) [36]: L. densiflorum (Guss.) Kuntze shoots (50-56 mg GAE/g DW) [37,38], L. algarvense leaves (54 mg GAE/g DW) [5], and L. morisianum Arrigoni aerial parts (59 mg GAE/g DW) [39]. These values are in the lower end of the range reported by Senizza et al. [40] and Ruiz-Riaguas et al. [8] for L. delicatulum, L. quesadense, L. bellidifolium (Gouan) Dumort., L. globuliferum (Boiss. and Heldr.) Kuntze, L. gmelinii, L. iconicum (Boiss. and Heldr.) Kuntze, L. lilacinum (Boiss. and Balansa) Wagenitz and L. sinuatum aerial parts extracts (44-172 mg GAE/g DW).

\subsection{Antimicrobial Activity of Limonium spp. Extracts}

The use of halophytes to obtain bioactive antimicrobial extracts is recent, and the effect of the natural products derived from them was generally evaluated against human pathogens (as in the case of the extracts from Pistacia atlantica Desf., Tamarix gallica L., T. articulata Vahl, Anabasis articulata (Forssk.) Moq. or Suaeda fructicosa (L.) Forssk. [41-44]), not against phytopathogens.

In the particular case of Limonium genus., antimicrobial studies were reported for other species, such as L. brasiliense [6], L. awei (De Not.) Brullo and Erben [45,46], L. morisianum [39], L. socotranum (Vierh.) Radcl.-Sm. [47], L. echioides [48], L. densiflorum [37], L. delicatulum [36], 
L. myrianthum, L. leptophyllum and L. gmelinii [49], but not for L. binervosum, so direct efficacy comparisons are not possible.

Regarding the antibacterial activity, Blainski et al. [6] reported a desirable inhibition of bacterial growth for the ethyl-acetate fraction of ternary extracts of $L$. brasiliense against vancomycin-resistant Enterococcus faecium, methicillin-resistant Staphylococcus aureus and Klebsiella pneumoniae, with MIC values of 19,39 and $625 \mu \mathrm{g} \cdot \mathrm{mL}^{-1}$, respectively. The activity of L. awei extracts was reported by Filocamo et al. [45], with MIC and minimum bactericidal concentration (MBC) values ranging from 15.6 to $500 \mu \mathrm{g} \cdot \mathrm{mL}^{-1}$ and from 500 to $4000 \mu \mathrm{g} \cdot \mathrm{mL}^{-1}$, respectively, against Gram-positive bacteria and $>2000 \mu \mathrm{g} \cdot \mathrm{mL}^{-1}$ for Gramnegative bacteria. For the same Limonium species, Nostro et al. [46] reported MIC and MBC values ranging from 7.8 to $62.5 \mu \mathrm{g} \cdot \mathrm{mL}^{-1}$ and from 500 to $2000 \mu \mathrm{g} \cdot \mathrm{mL}^{-1}$, respectively, against S. aureus (including methicillin-resistant strains). Recently, Mandrone et al. [39] found potent anti-staphylococcal properties for L. morisianum extract, with an average $\mathrm{IC}_{50}$ value of 9.2 [6.8-12.3] $\mu \mathrm{g} \cdot \mathrm{mL}^{-1}$. Moreover, recently, Al-Madhagi et al. [47] noted that methanol leaf and flower extracts from L. socotranum exhibited higher antibacterial activity against Micrococcus luteus (MIC $15.6 \mu \mathrm{g} \cdot \mathrm{mL}^{-1}$ ), S. aureus (MIC $125 \mu \mathrm{g} \cdot \mathrm{mL}^{-1}$ ) and Pseudomonas aeruginosa (MIC $125 \mu \mathrm{g} \cdot \mathrm{mL}^{-1}$ ) than stem extracts.

Concerning the antifungal activity of Limonium spp., a low antifungal activity was reported for L. echioides (against Fusarium oxysporum and Penicillium sp. [48]), for L. avei (against Candida albicans [46]), and for L. densiflorum and L. delicatilum (against Candida spp. [36,37]). Nonetheless, a stronger antifungal activity against $C$. albicans and Aspergillus niger, with full inhibition at concentrations as low as 62 and $125 \mu \mathrm{g} \cdot \mathrm{mL}^{-1}$, respectively, were found for L. socotranum leaf and flower extracts [47]. Significant antifungal activities against C. glabrata, with $\mathrm{IC}_{50}$ values in the $4.96-6.83 \mu \mathrm{g} \cdot \mathrm{mL}^{-1}$, were also reported for secondary metabolites from L. myrianthum, L. leptophyllum and L. gmelinii by Gadetskaya et al. [49].

\subsection{Antimicrobial Activity of the Main Identified Phytochemicals}

All the main phytochemicals found in the L. binervosum flower and leaf extracts have been reported to have both antimicrobial and antifungal activity (albeit not against any of the phytopathogens referred herein).

Eicosane is effective against bacteria such as Escherichia coli, Salmonella typhi and S. aureus [50], and against fungi such as Rhizoctonia solani [51]. Likewise, the antimicrobial activity of $\beta$-sitosterol against both bacteria (S. typhii, Corynebacterium diphtheriae, Bacillus subtilis, Shigella dysenteriae and Vibrio cholerae) and fungi (Fusarium spp. and Penicillium spp.) was reported by Kiprono et al. [52].

Concerning fatty acids, which are the major constituents of L. binervosum extracts, it was demonstrated that the antibacterial action of long-chain unsaturated fatty acids is mediated by the inhibition of fatty acid synthesis [53], and it was shown that both saturated and unsaturated fatty acids have antifungal activity, although saturated fatty acids would show a stronger activity [54]. In particular, antimicrobial properties of tetradecanoic acid were referred to in the literature (against, for instance, Listeria monocytogenes [55] and C. albicans [56]), as well as for its derivatives, such as methyl 2-hydroxytetradecanoate (against C. albicans, Cryptococcus neoformans and A. niger [57]). Regarding linolenic acid, Lee et al. [58] concluded that this fatty acid has a strong antibacterial activity against $B$. cereus and S. aureus, and Walters et al. [59] showed its activity against R. solani, Pythium ultimum, Pyrenophora avenae and Crinipellis perniciosa.

With regard to vitamin E, its antibacterial activity against E. coli, S. aureus, S. epidermidis, P. aeruginosa, Proteus spp., Klebsiella spp., and Enterobacter spp. was evidenced by Al-Salih et al. [60], and it was reported that-in combination with fluconazole-it results effective in the treatment of some human fungal diseases [61].

\subsection{On the Synergistic Behavior Observed for the Conjugate Complexes}

The combination of chitosan with several of the main constituents of L. binervosum extracts has precedents in the literature. For instance, combinations of chitosan with vitamin 
E were studied by Yeamsuksawat and Liang [62], Martins et al. [63] and Raza et al. [64]. The rationale behind such choice is that, while $\alpha$-tocopherol has feeble stability, it is improved by encapsulation in chitosan as a capping agent, as well as its release when required over a sustained period. Similarly, Liu et al. [65] reported the formation of self-assembled nanoparticles by coupling chitosan with linolenic acid, taking advantage of the fact that chitosan is known to inhibit the linoleic (and linolenic) acid oxidation process [66]. In the case of tetradecanoic acid, chitosan-tetradecanoic acid nanogels with MIC values of $10 \mathrm{mg} \cdot \mathrm{mL}^{-1}$ against $S$. enterica were reported by Rajaei et al. [67].

Nonetheless, none of the aforementioned combinations are conjugated complexes, and the existence of interactions between the two components in terms of antimicrobial activity was not explored. Albeit for other phytochemicals different from the ones present in L. binervosum, a synergistic behavior upon conjugation with COS was reported in the literature against phytopathogens: e.g., for horsetail (Equisetum arvense L.) and nettle (Urtica dioica L.) extracts against eight fungal species involved in grapevine trunk diseases [68], with $\mathrm{EC}_{90}$ values in the $208-1000 \mu \mathrm{g} \cdot \mathrm{mL}^{-1}$ range (depending on the extract and on the Botryosphaeriaceae taxa). The value reported in this work for the COS-flower extract complex $\left(914 \mu \mathrm{g} \cdot \mathrm{mL}^{-1}\right)$ would be on the upper limit.

For the same phytopathogens studied herein, and also for extracts from halophytes, MIC values of 375 and $500 \mu \mathrm{g} \cdot \mathrm{mL}^{-1}$ against X. ampelinus and 187.5 and $500 \mu \mathrm{g} \cdot \mathrm{mL}^{-1}$ against $E$. amylovora were found for the conjugate complexes formed between COS and rock samphire (Crithmum maritimum L.) and sea carrot (Daucus carota subsp. gummifer (Syme) Hook.fil.) hydromethanolic extracts, respectively. Such inhibition values are worse than the one reported herein against $X$. ampelinus for the COS-flower extract conjugate complex (MIC $\left.=250 \mu \mathrm{g} \cdot \mathrm{mL}^{-1}\right)$, but slightly better than/comparable to that obtained against E. amylovora (MIC $\left.=500 \mu \mathrm{g} \cdot \mathrm{mL}^{-1}\right)$ [69].

The mechanism of synergistic action of such COS-phytochemical conjugates has not been dilucidated yet. Nonetheless, it was suggested that it might be the result of an enhanced additive antimicrobial effect, per se, and/or via a concurrent action on diverse microbial metabolic sites. An increase in the cationic surface charge of COS may also result from conjugation with phytochemicals, which would enhance the linkage to negatively charged site-specific binding receptors on the bacterial/fungal membranes [70-73].

\section{Material and Methods}

\subsection{Reagents}

High-molecular weight (310,000-375,000 Da) chitosan (CAS 9012-76-4) was purchased from Hangzhou Simit Chem. and Tech. Co. (Hangzhou, China). Neutrase ${ }^{\mathrm{TM}} 0.8 \mathrm{~L}$ enzyme was obtained from Novozymes A/S (Bagsværd, Denmark). The preparation of chitosan oligomers (COS) was carried out according to the procedure reported by Santos-Moriano et al. [74], with the modifications indicated in [73].

Eicosane (CAS 112-95-8, 99\%), 1,2-tetradecanoic acid (CAS 544-63-8, Sigma Grade, $\geq 99 \%$ ), linolenic acid (CAS 463-40-1, $\geq 99 \%$ ), $\beta$-sitosterol (CAS 83-46-5, analytical standard), vitamin E ( $\alpha$-tocopherol, CAS 10191-41-0, analytical standard), methanol (CAS 67-56-1, UHPLC, suitable for MS), tryptic soy broth (TSB, CAS 8013-01-2) and tryptic soy agar (TSA, CAS 91079-40-2) were supplied by Sigma-Aldrich (Madrid, Spain). Potato dextrose agar (PDA) was acquired from Becton Dickinson (Bergen County, NJ, USA). All reagents were used as supplied without further purification.

\subsection{Plant Material and Extraction Procedure}

L. binervosum was collected in sea cliffs in Llanes (Asturias, Spain; $43^{\circ} 26^{\prime} 10.7^{\prime \prime} \mathrm{N}$ $4^{\circ} 49^{\prime} 25.1^{\prime \prime}$ W) in early September 2020. Separate composite samples of flowers and leaves were obtained by thoroughly mixing the aerial parts from different specimens $(n=15)$. The composite samples were shade-dried, pulverized in a mechanical grinder, homogenized and sieved (1 $\mathrm{mm}$ mesh). 
L. binervosum flower samples were mixed $(1: 20 w / v)$ with a 1:1 $v / v$ methanol:water solution and heated for $30 \mathrm{~min}$ in a water bath at $50{ }^{\circ} \mathrm{C}$. Subsequently, they were sonicated for $5 \mathrm{~min}$ in pulse mode with a $1 \mathrm{~min}$ stop for each $2.5 \mathrm{~min}$, using a Hielscher Ultrasonics (Teltow, Germany) probe-type ultrasonicator (model UIP1000hdT; $1000 \mathrm{~W}, 20 \mathrm{kHz}$ ). The solution was subjected to centrifugation at $9000 \mathrm{rpm}$ for $15 \mathrm{~min}$, and the supernatant was filtered through Whatman No. 1 paper. Aliquots were lyophilized for CHNS and FTIR analyses. The extraction procedure for leaf samples was identical.

Each extraction procedure was replicated three times (on subsamples of the flower and leaf composite samples), and the resulting hydromethanolic extracts were mixed to obtain the samples for GC-MS analysis.

\subsection{Bacterial and Fungal Isolates}

The X. ampelinus and E. amylovora bacterial isolates were supplied by CECT (Valencia, Spain), with CCUG 21976 and NCPPB 595 strain designations, respectively. D. seriata (isolate Y-084-01-01a, code ITACYL_F098), obtained from "Tempranillo" grapevine plants from P.D.O. Toro (Spain), was supplied by ITACYL (Valladolid, Spain) [75] as a lyophilized vial, which was reconstituted and refreshed as a PDA subculture.

\subsection{Physicochemical Characterization}

Elemental analyses of dry ground samples ( $3 \mathrm{mg} / \mathrm{sample}$ ) were performed with a CHNS-932 apparatus (LECO, St. Joseph, MI, USA).

Calorific values were calculated from elemental analysis data according to Talwalkar et al. [76], using the following equation:

$$
\mathrm{HHV}=(0.341 \times \% \mathrm{C})+(1.322 \times \% \mathrm{H})-0.12(\% \mathrm{O}+\% \mathrm{~N}),
$$

where $\mathrm{HHV}$ is the heating value for the dry material, expressed in $\mathrm{kJ} \cdot \mathrm{g}^{-1}$, and $\% \mathrm{C}, \% \mathrm{H}$, $\% \mathrm{O}$ and $\% \mathrm{~N}$ are the mass fractions, expressed in $\mathrm{wt} \%$ of dry material.

Thermal gravimetric (TGA) and differential scanning calorimetry (DSC) analyses were conducted with a simultaneous TG-DSC2 apparatus (Mettler Toledo; Columbus, $\mathrm{OH}$, USA). Samples (10 mg/sample) were heated from 30 to $600{ }^{\circ} \mathrm{C}$ under $\mathrm{N}_{2}: \mathrm{O}_{2}$ (4:1) flow $\left(20 \mathrm{~cm}^{3} \cdot \mathrm{min}^{-1}\right)$, at a $20^{\circ} \mathrm{C} \cdot \mathrm{min}^{-1}$ heating rate.

The infrared spectra were obtained with a Nicolet iS50 Fourier-transform infrared spectrometer (Thermo Scientific; Waltham, MA, USA), equipped with an in-built diamond attenuated total reflection (ATR) system. A spectral resolution of $1 \mathrm{~cm}^{-1}$ over the $400-4000 \mathrm{~cm}^{-1}$ range was used, taking the interferograms that resulted from co-adding 64 scans.

The colorimetric quantification of the total polyphenol content (TPC), expressed in gallic acid equivalents (GAE), was conducted according to the procedure described in [77], using a UV-Vis Cary 100 spectrometer (Agilent Technologies; Santa Clara, CA, USA).

The gas chromatography-mass spectrometry (GC-MS) analyses of the hydroalcoholic plant extracts (obtained as a mixture of three extractions) were carried out at the Research Support Services (STI) at Universidad de Alicante (Alicante, Spain). A model 7890A gas chromatograph coupled to a model 5975C quadrupole mass spectrometer (Agilent Technologies). The chromatographic conditions were: 3 injections/vial; $1 \mu \mathrm{L}$ injection volume; $280^{\circ} \mathrm{C}$ injector temperature, in splitless mode; the $60^{\circ} \mathrm{C}$ initial oven temperature was held for $2 \mathrm{~min}$, followed by a $10^{\circ} \mathrm{C} \cdot \mathrm{min}^{-1} \mathrm{ramp}$ up to a $300^{\circ} \mathrm{C}$ final temperature, kept for $15 \mathrm{~min}$. The chromatographic column used for the separation of the compounds was an HP-5MS UI (Agilent Technologies) of $30 \mathrm{~m}$ length, $0.250 \mathrm{~mm}$ diameter and $0.25 \mu \mathrm{m}$ film. The MS conditions were: temperature of the electron impact source of the mass spectrometer $=230^{\circ} \mathrm{C}$ and of the quadrupole $=150{ }^{\circ} \mathrm{C} ; 70 \mathrm{eV}$ ionization energy. Equipment calibration was conducted using test mixture 2 for apolar capillary columns according to Grob (Supelco 86501) and PFTBA tuning standards. Compound identification was carried out using the NIST11 library [78]. 


\subsection{In Vitro Antibacterial Activity Assessment}

The antibacterial activity was assessed by determining the minimum inhibitory concentration (MIC). The agar dilution method was used, according to CLSI standard M07-11 [79]. An isolated colony of X. ampelinus was incubated in TSB liquid medium at $26^{\circ} \mathrm{C}$ for $18 \mathrm{~h}$. Starting from a $10^{8} \mathrm{CFU} \cdot \mathrm{mL}^{-1}$ concentration, serial dilutions were then conducted to obtain a final inoculum of $\sim 10^{4} \mathrm{CFU} \cdot \mathrm{mL}^{-1}$. Subsequently, bacterial suspensions were delivered to the surface of TSA plates amended with the treatments at concentrations ranging from 62.5 to $1500 \mu \mathrm{g} \cdot \mathrm{mL}^{-1}$. The plates were incubated at $26^{\circ} \mathrm{C}$ for $24 \mathrm{~h}$. The procedure for E. amylovora was identical, except for the incubation temperature $\left(30^{\circ} \mathrm{C}\right)$. MICs were visually determined as the lowest concentrations at which no bacterial growth was visible in the agar dilutions. All experiments were run in triplicate, with each replicate consisting of 3 plates per treatment/concentration.

\subsection{In Vitro Antifungal Activity Assessment}

The antifungal activity of the different treatments was determined according to EUCAST standard antifungal susceptibility testing procedures [80], using the agar dilution method. Aliquots of stock solutions were incorporated onto the PDA medium to obtain concentrations in the $62.5-1500 \mu \mathrm{g} \cdot \mathrm{mL}^{-1}$ range. Mycelial plugs ( $5 \mathrm{~mm}$ in diameter), taken from the margin of 7-day-old D. seriata PDA cultures, were transferred to plates amended with aforementioned concentrations of each treatment (3 plates per treatment/concentration, with 2 replicates). Plates were incubated in the dark at $25^{\circ} \mathrm{C}$ for 7 days. PDA medium without any amendment was used as the control. Mycelial growth inhibition was estimated according to the formula:

$$
\left(\left(d_{c}-d_{t}\right) / d_{c}\right) \times 100,
$$

where $d_{\mathrm{c}}$ and $d_{t}$ represent the average diameters of the fungal colony of the control and of the treated fungal colony, respectively. $\mathrm{EC}_{50}$ and $\mathrm{EC}_{90}$ effective concentrations were estimated in IBM SPSS Statistics v.25 (IBM; Armonk, NY, USA) software using PROBIT analysis. The level of interaction was determined according to Wadley's method [81].

\subsection{Statistical Analysis}

Given that the homogeneity and homoscedasticity requirements were satisfied (according to Shapiro-Wilk and Levene tests, respectively), the mycelial growth inhibition results for D. seriata were statistically analyzed in IBM SPSS Statistics v.25 software using one-way analysis of variance (ANOVA), followed by post hoc comparison of means through Tukey's test at $p<0.05$.

\section{Conclusions}

A halophyte from the cliffs of the Atlantic coasts of Europe, viz. Limonium binervosum (rock sea-lavender) was studied by elemental and thermal analysis, FTIR spectroscopy and GC-MS with a view to its valorization. The use of its biomass as a solid biofuel can be ruled out, given that its higher heating value (in the $16-18 \mathrm{~kJ} \cdot \mathrm{g}^{-1}$ range) and content of ashes (5.6\% and $17 \%$ for flowers and leaves, respectively) do not meet the minimum legal requirements, but its high content in fatty acids open the door to potential exploitation as a biofuel feedstock. Another potential application would be related to the use of its hydrometanolic extracts as natural biocontrol products, given that phytochemicals with antimicrobial properties were found in significant amounts: both flower and leaf extracts contained eicosane (4-18\%), $\beta$-sitosterol (9-19\%) and tocopherols (7-13\%), besides fatty acids and their esters (22\% of tetradecanoic acid in the flower extract, and $30 \%$ of linolenic and linoleic acids in the leaf extract). The inhibitory activity of the extracts and their main constituents, alone or in combination with chitosan oligomers, was tested in vitro against $X$. ampelinus, E. amylovora and D. seriata phytopathogens. A remarkable antibacterial activity was observed against X. ampelinus (with a MIC value of $250 \mu \mathrm{g} \cdot \mathrm{mL}^{-1}$ ) and E. amylovora $\left(\mathrm{MIC}=500 \mu \mathrm{g} \cdot \mathrm{mL}^{-1}\right.$ ) for the conjugated complex of the flower extract with COS, which also resulted in an $\mathrm{EC}_{90}$ of $914 \mu \mathrm{g} \cdot \mathrm{mL}^{-1}$ against $D$. seriata. In view of these results, the 
conjugate complexes of this halophyte may be put forward as promising antimicrobial treatments for apple tree and grapevine diseases in organic agriculture.

Supplementary Materials: The following are available online at https:/ / www.mdpi.com/article/10 .3390/ plants10091852/s1, Figure S1: TG, DTG and DSC curves for L. binervosum flowers, Figure S2: TG, DTG and DSC curves for L. binervosum leaves, Figure S3: GC-MS spectrum of L. binervosum flower hydromethanolic extract, Figure S4: GC-MS spectrum of L. binervosum leaf hydromethanolic extract, Figure S5: Growth inhibition of D. seriata for the conjugate complexes under study, Table S1: GC-MS results for the L. binervosum flower hydromethanolic extract, Table S2: GC-MS results for the L. binervosum leaf hydromethanolic extract.

Author Contributions: Conceptualization, J.M.-G. and P.M.-R.; methodology, B.L.-V. and J.C.-G.; validation, B.L.-V., J.C.-G. and J.M.-G.; formal analysis, J.C.-G. and P.M.-R.; investigation, E.S.-H., L.B.-D., N.L.-L., J.C.-G., B.L.-V., J.M.-G. and P.M.-R.; resources, J.M.-G. and P.M.-R.; writing-original draft preparation, E.S.-H., L.B.-D., N.L.-L., J.C.-G., B.L.-V., J.M.-G. and P.M.-R.; writing-review and editing, P.M.-R.; visualization, E.S.-H. and L.B.-D.; supervision, P.M.-R.; project administration, J.M.-G. and P.M.-R.; funding acquisition, J.M.-G. and P.M.-R. All authors have read and agreed to the published version of the manuscript.

Funding: This research was funded by Junta de Castilla y León under project VA258P18, with FEDER co-funding, by Cátedra Agrobank under "IV Convocatoria de Ayudas de la Cátedra AgroBank para la transferencia del conocimiento al sector agroalimentario" program; by Fundación IbercajaUniversidad de Zaragoza under the "Convocatoria Fundación Ibercaja-Universidad de Zaragoza de proyectos de investigación, desarrollo e innovación para jóvenes investigadores” program.

Institutional Review Board Statement: Not applicable.

Informed Consent Statement: Not applicable.

Data Availability Statement: The data presented in this study are available on request from the corresponding author. The data are not publicly available due to their relevance to be part of an ongoing Ph.D. Thesis.

Acknowledgments: The authors gratefully acknowledge the support of Pilar Blasco and Pablo Candela at the Servicios Técnicos de Investigación, Universidad de Alicante, for conducting the GC-MS analyses.

Conflicts of Interest: The funders had no role in the design of the study; in the collection, analyses, or interpretation of data; in the writing of the manuscript, or in the decision to publish the results.

\section{References}

1. Caperta, A.D.; Castro, S.; Loureiro, J.; Róis, A.; Conceição, S.; Costa, J.; Rhazi, L.; Santo, D.E.; Arsénio, P. Biogeographical, ecological and ploidy variation in related asexual and sexual Limoniumtaxa (Plumbaginaceae). Bot. J. Linn. Soc. 2016, 183, 75-93. [CrossRef]

2. Lledó, M.D.; Crespo, M.B.; Fay, M.F.; Chase, M.W. Molecular phylogenetics of Limonium and related genera (Plumbaginaceae): Biogeographical and systematic implications. Am. J. Bot. 2005, 92, 1189-1198. [CrossRef] [PubMed]

3. Salmon, C.E. Limonium binervosum Salm. In Reports of the Botanical Society and Exchange Club; Report for 1922; Druce, G.C., Ed.; T. Buncle \& Co.: Arbroath, UK, 1923; Volume 7, p. 1054.

4. Ingrouille, M.J.; Stace, C.A. The Limonium binervosum aggregate (Plumbaginaceae) in the British Isles. Bot. J. Linn. Soc. 1986, 92, 177-217. [CrossRef]

5. $\quad$ Rodrigues, M.J.; Soszynski, A.; Martins, A.; Rauter, A.; Neng, N.R.; Nogueira, J.M.; Varela, J.; Barreira, L.; Custódio, L. Unravelling the antioxidant potential and the phenolic composition of different anatomical organs of the marine halophyte Limonium algarvense. Ind. Crop. Prod. 2015, 77, 315-322. [CrossRef]

6. Blainski, A.; Gionco, B.; Oliveira, A.G.; Andrade, G.; Scarminio, I.S.; Silva, D.B.; Lopes, N.P.; Mello, J.C. Antibacterial activity of Limonium brasiliense (Baicuru) against multidrug-resistant bacteria using a statistical mixture design. J. Ethnopharmacol. 2017, 198, 313-323. [CrossRef] [PubMed]

7. Geng, D.; Chi, X.; Dong, Q.; Hu, F. Antioxidants screening in Limonium aureum by optimized on-line HPLC-DPPH assay. Ind. Crop. Prod. 2015, 67, 492-497. [CrossRef]

8. Ruiz-Riaguas, A.; Zengin, G.; Sinan, K.; Salazar-Mendías, C.; Llorent-Martínez, E. Phenolic Profile, Antioxidant Activity, and Enzyme Inhibitory Properties of Limonium delicatulum (Girard) Kuntze and Limonium quesadense Erben. J. Chem. 2020, 2020, 1-10. [CrossRef] 
9. Mutlu-Ingok, A.; Devecioglu, D.; Dikmetas, D.N.; Karbancioglu-Guler, F.; Capanoglu, E. Antibacterial, Antifungal, Antimycotoxigenic, and Antioxidant Activities of Essential Oils: An Updated Review. Molecules 2020, 25, 4711. [CrossRef]

10. Willems, A.; Gillis, M.; Kersters, K.; Broecke, L.V.D.; De Ley, J. Transfer of Xanthomonas ampelina Panagopoulos 1969 to a New Genus, Xylophilus gen. nov., as Xylophilus ampelinus (Panagopoulos 1969) comb. nov. Int. J. Syst. Bacteriol. 1987, 37, 422-430. [CrossRef]

11. Szegedi, E.; Civerolo, E.L. Bacterial diseases of grapevine. Int. J. Hortic. Sci. 2011, 17, 45-49. [CrossRef]

12. Donat, V.; Biosca, E.; Peñalver, J.; Lopez, M. Exploring diversity among Spanish strains of Erwinia amylovora and possible infection sources. J. Appl. Microbiol. 2007, 103, 1639-1649. [CrossRef] [PubMed]

13. Larignon, P.; Fulchic, R.; Cere, L.; Dubos, B. Observation on Black Dead Arm in French Vineyards. Phytopathol. Mediterr. 2001, 40, 336-342. [CrossRef]

14. Mondello, V.; Songy, A.; Battiston, E.; Pinto, C.; Coppin, C.; Trotel-Aziz, P.; Clément, C.; Mugnai, L.; Fontaine, F. Grapevine Trunk Diseases: A Review of Fifteen Years of Trials for Their Control with Chemicals and Biocontrol Agents. Plant Dis. 2018, 102, 1189-1217. [CrossRef]

15. Stevens, N.E. Two Apple Black Rot Fungi in the United States. Mycologia 1933, 25, 536-548. [CrossRef]

16. Brown-Rytlewski, D.E.; McManus, P.S. Virulence of Botryosphaeria dothidea and Botryosphaeria obtusa on Apple and Management of Stem Cankers with Fungicides. Plant Dis. 2000, 84, 1031-1037. [CrossRef]

17. Ii, E.A.B. BotryosphaeriaDiseases of Apple and Peach in the Southeastern Unites Stated. Plant Dis. 1986, 70, 480. [CrossRef]

18. Kanakiya, A.; Padalia, H.; Pande, J.; Chanda, S. Physicochemical, phytochemical and pharmacognostic study of Limonium stocksii. A halophyte from Gujarat. J. Phytopharm. 2018, 7, 312-318.

19. da Luz, B.R. Attenuated total reflectance spectroscopy of plant leaves: A tool for ecological and botanical studies. New Phytol. 2006, 172, 305-318. [CrossRef] [PubMed]

20. Socrates, G. Infrared and Raman Characteristic Group Frequencies: Tables and Charts, 3rd ed.; Wiley: Chichester, NY, USA, $2001 ;$ p. 347.

21. Mot, A.; Silaghi-Dumitrescu, R.; Sarbu, C. Rapid and effective evaluation of the antioxidant capacity of propolis extracts using DPPH bleaching kinetic profiles, FT-IR and UV-vis spectroscopic data. J. Food Compos. Anal. 2011, 24, 516-522. [CrossRef]

22. Junior, V.; Arruda, I.; Bemme, L. Caracterização térmica e espectroscópica de microcápsulas de quitosana incorporada de própolis. Rev. Eletrônica da Univar 2013, 2, 161-165.

23. Silva, A.J.; Silva, J.R.; de Souza, N.; Souto, P.C.D.S. Membranes from latex with propolis for biomedical applications. Mater. Lett. 2014, 116, 235-238. [CrossRef]

24. Park, S.-I.; Hwang, Y.-S.; Um, J.-S. Estimating blue carbon accumulated in a halophyte community using UAV imagery: A case study of the southern coastal wetlands in South Korea. J. Coast. Conserv. 2021, 25, 1-9. [CrossRef]

25. Ochoa-Hueso, R.; Corona, M.E.P.; Manrique, E. Impacts of Simulated N Deposition on Plants and Mycorrhizae from Spanish Semiarid Mediterranean Shrublands. Ecosystems 2013, 16, 838-851. [CrossRef]

26. Duca, D.; Riva, G.; Pedretti, E.F.; Toscano, G. Wood pellet quality with respect to EN 14961-2 standard and certifications. Fuel 2014, 135, 9-14. [CrossRef]

27. Patel, M.K.; Pandey, S.; Brahmbhatt, H.R.; Mishra, A.; Jha, B. Lipid content and fatty acid profile of selected halophytic plants reveal a promising source of renewable energy. Biomass Bioenergy 2019, 124, 25-32. [CrossRef]

28. Gadetskaya, A.; Zhusupova, G.; Ross, S. Composition of the volatile oil from aerial parts of Limonium genus. Chem. J. Kazakhstan 2015, 2, 274-279.

29. Korul'Kina, L.M.; Zhusupova, G.E.; Shul'Ts, E.E.; Erzhanov, K.B. Fatty-acid composition of two Limonium plant species. Chem. Nat. Compd. 2004, 40, 417-419. [CrossRef]

30. Bashir, A.; Abdalla, A.A.; Wasfi, I.A.; Hassan, E.S.; Amiri, M.H.; Crabb, T.A. Flavonoids of Limonium axillare. Int. J. Pharmacogn. 1994, 32, 366-372. [CrossRef]

31. Yurchyshyn, O.; Rusko, G.; Kutsyk, R. Antimicrobial effect of south Ukrainian sea lavender Limonium meyeri (Boiss.) O. Kuntze and Limonium hypanicum Klok. with especial emphasizing against staphylococci and Propionibacteria. Pharma Innov. J. 2017, 6, 380-384.

32. Taheri, Y.; Suleria, H.A.R.; Martins, N.; Sytar, O.; Beyatli, A.; Yeskaliyeva, B.; Seitimova, G.; Salehi, B.; Semwal, P.; Painuli, S.; et al. Myricetin bioactive effects: Moving from preclinical evidence to potential clinical applications. BMC Complement. Med. Ther. 2020, 20,1-14. [CrossRef]

33. Marinova, E.; Toneva, A.; Yanishlieva, N. Synergistic antioxidant effect of $\alpha$-tocopherol and myricetin on the autoxidation of triacylglycerols of sunflower oil. Food Chem. 2008, 106, 628-633. [CrossRef]

34. Li, A.-N.; Li, S.; Li, H.-B.; Xu, D.-P.; Xu, X.-R.; Chen, F. Total phenolic contents and antioxidant capacities of 51 edible and wild flowers. J. Funct. Foods 2014, 6, 319-330. [CrossRef]

35. Skrajda, M.N. Phenolic compounds and antioxidant activity of edible flowers. J. Educ. Health Sport 2017, 7, 946-956.

36. Medini, F.; Fellah, H.; Ksouri, R.; Abdelly, C. Total phenolic, flavonoid and tannin contents and antioxidant and antimicrobial activities of organic extracts of shoots of the plant Limonium delicatulum. J. Taibah Univ. Sci. 2014, 8, 216-224. [CrossRef]

37. Medini, F. Effects of physiological stage and solvent on polyphenol composition, antioxidant and antimicrobial activities of Limonium densiflorum. J. Med. Plants Res. 2011, 5. [CrossRef] 
38. Medini, F.; Bourgou, S.; Lalancette, K.; Snoussi, M.; Mkadmini, K.; Coté, I.; Abdelly, C.; Legault, J.; Ksouri, R. Phytochemical analysis, antioxidant, anti-inflammatory, and anticancer activities of the halophyte Limonium densiflorum extracts on human cell lines and murine macrophages. S. Afr. J. Bot. 2015, 99, 158-164. [CrossRef]

39. Mandrone, M.; Bonvicini, F.; Lianza, M.; Sanna, C.; Maxia, A.; Gentilomi, G.; Poli, F. Sardinian plants with antimicrobial potential. Biological screening with multivariate data treatment of thirty-six extracts. Ind. Crop. Prod. 2019, 137, 557-565. [CrossRef]

40. Senizza, B.; Zhang, L.; Rocchetti, G.; Zengin, G.; Ak, G.; Y1ldıztugay, E.; Elbasan, F.; Jugreet, S.; Mahomoodally, M.F.; Lucini, L. Metabolomic profiling and biological properties of six Limonium species: Novel perspectives for nutraceutical purposes. Food Funct. 2021, 12, 3443-3454. [CrossRef]

41. Belyagoubi-Benhammou, N.; Belyagoubi, L.; Gismondi, A.; DI Marco, G.; Canini, A.; Bekkara, F.A. GC/MS analysis, and antioxidant and antimicrobial activities of alkaloids extracted by polar and apolar solvents from the stems of Anabasis articulata. Med. Chem. Res. 2019, 28, 754-767. [CrossRef]

42. Benmahieddine, A.; Belyagoubi-Benhammou, N.; Belyagoubi, L.; El Zerey-Belaskri, A.; Gismondi, A.; Di Marco, G.; Canini, A.; Bechlaghem, N.; Bekkara, F.A.; Djebli, N. Influence of plant and environment parameters on phytochemical composition and biological properties of Pistacia atlantica Desf. Biochem. Syst. Ecol. 2021, 95, 104231. [CrossRef]

43. Saïdana, D.; Mahjoub, S.; Boussaada, O.; Chriaa, J.; Mahjoub, M.A.; Chéraif, I.; Daami, M.; Mighri, Z.; Helal, A.N. Antibac-terial and antifungal activities of the essential oils of two saltcedar species from Tunisia. J. Am. Oil Chem. Soc. 2008, 85, 817-826. [CrossRef]

44. Tabet, A.; Boukhari, A. Antioxidant and antibacterial activities of two Algerian halophytes. Int. J. Pharm. Sci. Rev. Res. 2018, 50, 114-121.

45. Filocamo, A.; Nostro, A.; Giovannini, A.; Catania, S.; Costa, C.; Marino, A.; Bisignano, G. Antimicrobial activity of Limonium avei (De Not.) Brullo \& Erben extracts. Planta Med. 2010, 76, P465. [CrossRef]

46. Nostro, A.; Filocamo, A.; Giovannini, A.; Catania, S.; Costa, C.; Marino, A.; Bisignano, G. Antimicrobial activity and phenolic content of natural site and micropropagated Limonium avei (De Not.) Brullo \& Erben plant extracts. Nat. Prod. Res. 2011, 26, 1-5. [CrossRef]

47. Al-Madhagi, W.M.; Hashim, N.M.; Ali, N.A.A.; Othman, R. Phytochemical screening, cytotoxic and antimicrobial activities of Limonium socotranum and Peperomia blanda extracts. Trop. Biomed. 2019, 36, 11-21.

48. Saidana, D.; Boussaada, O.; Ayed, F.; Mahjoub, M.A.; Mighri, Z.; Helal, A.N. Thein vitrofree radical-scavenging and antifungal activities of the medicinal Herblimonium Echioides L. growing wild in Tunisia. J. Food Process. Preserv. 2012, 37, 533-540. [CrossRef]

49. Gadetskaya, A.; Mohamed, S.; Tarawneh, A.; Ma, G.; Ponomarev, B.; Zhussupova, G.; Cantrell, C.; Cutler, S.; Ross, S. Biologically potent metabolites from Limonium species. Planta Med. 2016, 81, S1-S381. [CrossRef]

50. Firdaus, M.; Kartikaningsih, H.; Sulifah, U. Sargassum spp extract inhibits the growth of foodborne illness bacteria. AIP Conf. Proc. 2019, 2202, 020083. [CrossRef]

51. Ahsan, T.; Chen, J.; Zhao, X.; Irfan, M.; Wu, Y. Extraction and identification of bioactive compounds (eicosane and dibutyl phthalate) produced by Streptomyces strain KX852460 for the biological control of Rhizoctonia solani AG-3 strain KX852461 to control target spot disease in tobacco leaf. AMB Express 2017, 7, 54. [CrossRef]

52. Kiprono, P.C.; Kaberia, F.; Keriko, J.M.; Karanja, J.N. The in vitro Anti-Fungal and Anti-Bacterial Activities of $\beta$-Sitosterol from Senecio lyratus (Asteraceae). Z. Naturforsch. C. J. Biosci. 2000, 55, 485-488. [CrossRef]

53. Zheng, C.J.; Yoo, J.-S.; Lee, T.-G.; Cho, H.-Y.; Kim, Y.-H.; Kim, W.-G. Fatty acid synthesis is a target for antibacterial activity of unsaturated fatty acids. FEBS Lett. 2005, 579, 5157-5162. [CrossRef] [PubMed]

54. Liu, S.; Ruan, W.; Li, J.; Xu, H.; Wang, J.; Gao, Y.; Wang, J. Biological Control of Phytopathogenic Fungi by Fatty Acids. Mycopathologia 2008, 166, 93-102. [CrossRef] [PubMed]

55. Chen, X.; Zhao, X.; Deng, Y.; Bu, X.; Ye, H.; Guo, N. Antimicrobial potential of myristic acid against Listeria monocytogenes in milk. J. Antibiot. 2019, 72, 298-305. [CrossRef] [PubMed]

56. Prasath, K.G.; Sethupathy, S.; Pandian, S.K. Proteomic analysis uncovers the modulation of ergosterol, sphingolipid and oxidative stress pathway by myristic acid impeding biofilm and virulence in Candida albicans. J. Proteom. 2019, 208, 103503. [CrossRef] [PubMed]

57. Carballeira, N.M.; O'Neill, R.; Parang, K. Synthesis and antifungal properties of $\alpha$-methoxy and $\alpha$-hydroxyl substituted 4thiatetradecanoic acids. Chem. Phys. Lipids 2007, 150, 82-88. [CrossRef]

58. Lee, J.-Y.; Kim, Y.-S.; Shin, D.-H. Antimicrobial Synergistic Effect of Linolenic Acid and Monoglyceride againstBacillus cereusandStaphylococcus aureus. J. Agric. Food Chem. 2002, 50, 2193-2199. [CrossRef]

59. Raynor, L.; Mitchell, A.; Walker, R. Antifungal Activities of Four Fatty Acids against Plant Pathogenic Fungi. Mycopathologia 2004, 157, 87-90. [CrossRef] [PubMed]

60. Al-Salih, D.A.A.K.; Aziz, F.M.; Mshimesh, B.A.R.; Jehad, M.T. Antibacterial effects of vitamin E: In vitro study. J. Biotechnol. Res. Cent. 2013, 7, 17-23.

61. Baran, R.; Thomas, L. Combination of fluconazole and alpha-tocopherol in the treatment of yellow nail syndrome. J. Drugs Dermatol. JDD 2009, 8, 276-278.

62. Yeamsuksawat, T.; Liang, J. Characterization and release kinetic of crosslinked chitosan film incorporated with $\alpha$-tocopherol. Food Packag. Shelf Life 2019, 22, 100415. [CrossRef] 
63. Martins, J.T.; Cerqueira, M.; Vicente, A.A. Influence of $\alpha$-tocopherol on physicochemical properties of chitosan-based films. Food Hydrocoll. 2012, 27, 220-227. [CrossRef]

64. Raza, Z.A.; Abid, S.; Azam, A.; Rehman, A. Synthesis of alpha-tocopherol encapsulated chitosan nano-assemblies and their impregnation on cellulosic fabric for potential antibacterial and antioxidant cosmetotextiles. Cellulose 2019, 27, 1717-1731. [CrossRef]

65. Liu, C.-G.; Desai, K.G.H.; Chen, A.X.-G.; Park, H.-J. Linolenic Acid-Modified Chitosan for Formation of Self-Assembled Nanoparticles. J. Agric. Food Chem. 2004, 53, 437-441. [CrossRef] [PubMed]

66. Kurniasih, M.; Purwati; Dewi, R.S. Toxicity tests, antioxidant activity, and antimicrobial activity of chitosan. IOP Conf. Ser. Mater. Sci. Eng. 2018, 349, 012037. [CrossRef]

67. Rajaei, A.; Hadian, M.; Mohsenifar, A.; Rahmani-Cherati, T.; Tabatabaei, M. A coating based on clove essential oils encapsulated by chitosan-myristic acid nanogel efficiently enhanced the shelf-life of beef cutlets. Food Packag. Shelf Life 2017, 14, 137-145. [CrossRef]

68. Langa-Lomba, N.; Buzón-Durán, L.; Martín-Ramos, P.; Casanova-Gascón, J.; Martín-Gil, J.; Sánchez-Hernández, E.; GonzálezGarcía, V. Assessment of Conjugate Complexes of Chitosan and Urtica dioica or Equisetum arvense Extracts for the Control of Grapevine Trunk Pathogens. Agronomy 2021, 11, 976. [CrossRef]

69. Sánchez-Hernández, E.; Buzón-Durán, L.; Andrés-Juan, C.; Lorenzo-Vidal, B.; Martín-Gil, J.; Martín-Ramos, P. Physicochemical Characterization of Crithmum maritimum L. and Daucus carota subsp. gummifer (Syme) Hook.fil. and Their Antimicrobial Activity against Apple Tree and Grapevine Phytopathogens. Agronomy 2021, 11, 886. [CrossRef]

70. Liang, C.; Yuan, F.; Liu, F.; Wang, Y.; Gao, Y. Structure and antimicrobial mechanism of $\varepsilon$-polylysine-chitosan conjugates through Maillard reaction. Int. J. Biol. Macromol. 2014, 70, 427-434. [CrossRef] [PubMed]

71. Buzón-Durán, L.; Langa-Lomba, N.; González-García, V.; Casanova-Gascón, J.; Martín-Gil, J.; Pérez-Lebeña, E.; Martín-Ramos, P. On the Applicability of Chitosan Oligomers-Amino Acid Conjugate Complexes as Eco-Friendly Fungicides against Grapevine Trunk Pathogens. Agronomy 2021, 11, 324. [CrossRef]

72. Buzón-Durán, L.; Martín-Gil, J.; Marcos-Robles, J.L.; Fombellida-Villafruela, A.; Pérez-Lebeña, E.; Martín-Ramos, P. Antifungal Activity of Chitosan Oligomers-Amino Acid Conjugate Complexes against Fusarium culmorum in Spelt (Triticum spelta L.). Agronomy 2020, 10, 1427. [CrossRef]

73. Buzón-Durán, L.; Martín-Gil, J.; Pérez-Lebeña, E.; Ruano-Rosa, D.; Revuelta, J.L.; Casanova-Gascón, J.; Ramos-Sánchez, M.C.; Martín-Ramos, P. Antifungal Agents Based on Chitosan Oligomers, $\varepsilon$-polylysine and Streptomyces spp. Secondary Metabolites against Three Botryosphaeriaceae Species. Antibiotics 2019, 8, 99. [CrossRef] [PubMed]

74. Santos-Moriano, P.; Fernandez-Arrojo, L.; Mengíbar, M.; Belmonte-Reche, E.; Peñalver, P.; Acosta, F.N.; Ballesteros, A.O.; Morales, J.C.; Kidibule, P.; Fernandez-Lobato, M.; et al. Enzymatic production of fully deacetylated chitooligosaccharides and their neuroprotective and anti-inflammatory properties. Biocatal. Biotransform. 2017, 36, 57-67. [CrossRef]

75. Martin, M.T.; Cobos, R. Identification of Fungi Associated with Grapevine Decline in Castilla y León (Spain). Phytopathol. Mediterr. 2007, 46, 18-25. [CrossRef]

76. Talwalkar, A.T. IGT/DOE Coal-Conversion Systems Technical Data Book; Institute of Gas Technology: Chicago, IL, USA, 1981; p. 23.

77. Jallali, I.; Zaouali, Y.; Missaoui, I.; Smeoui, A.; Abdelly, C.; Ksouri, R. Variability of antioxidant and antibacterial effects of essential oils and acetonic extracts of two edible halophytes: Crithmum Maritimum L. and Inula Crithmoïdes L. Food Chem. 2014, 145, 1031-1038. [CrossRef] [PubMed]

78. Langa-Lomba, N.; Sánchez-Hernández, E.; Buzón-Durán, L.; González-García, V.; Casanova-Gascón, J.; Martín-Gil, J.; MartínRamos, P. Activity of Anthracenediones and Flavoring Phenols in Hydromethanolic Extracts of Rubia tinctorum against Grapevine Phytopathogenic Fungi. Plants 2021, 10, 1527. [CrossRef]

79. CLSI. Methods for Dilution Antimicrobial Susceptibility Tests for Bacteria that Grow Aerobically, 11th ed.; CLSI standard M07; Clinical and Laboratory Standards Institute: Wayne, PA, USA, 2018.

80. Arendrup, M.C.; Cuenca-Estrella, M.; Lass-Flörl, C.; Hope, W. EUCAST technical note on the EUCAST definitive document EDef 7.2: Method for the determination of broth dilution minimum inhibitory concentrations of antifungal agents for yeasts EDef 7.2 (EUCAST-AFST). Clin. Microbiol. Infect. 2012, 18, E246-E247. [CrossRef]

81. Levy, Y.; Benderly, M.; Cohen, Y.; Gisi, U.; Bassand, D. The joint action of fungicides in mixtures: Comparison of two methods for synergy calculation. EPPO Bull. 1986, 16, 651-657. [CrossRef] 